\title{
The Implementation of Metacognition in Teaching Character Education at Primary Education
}

\author{
Elisabeth Avryanne Suminto ${ }^{1}$, Concilianus Laos Mbato ${ }^{2}$ \\ elisabethavryanne@gmail.com ${ }^{1}$, cons@usd.ac.id² \\ ${ }^{1}$ Factulty of Teachers Training and Education, Sanata Dharma University, Yogyakarta, \\ Indonesia \\ ${ }^{2}$ Factulty of Teachers Training and Education, Sanata Dharma University, Yogyakarta \\ Indonesia
}

Received: 09 March 2020 Accepted: 02 June 2020

DOI: $10.24256 /$ ideas.v8i1.1255

\begin{abstract}
Metacognition is concerned with a person's awareness of his or her own thinking processes. It is essential to study the implementation of metacognition in teaching character education since it serves as the basis for the teachers to guide the students into holistic learning. This research focused on the teachers' perceptions on the implementation of metacognition in character education. In particular, it aimed to obtain the information about the extent to which metacognition in character education in primary education led the teachers to school vision. The researchers employed mixed-method research involving twenty-one primary school teachers in a primary school in the Magelang region, Central Java. The instrument used were questionnaire and interview. The findings of this research showed that the teachers perceived the implementation of metacognition in teaching character education positively. However, the results of the interview revealed that they did not implement regulation of cognition wholly. Furthermore, the results of the open-ended questionnaire showed that there were four values which were well-implemented i.e., compassion, celebration, competence, and conviction. For the future research, therefore, urges future researchers to conduct a research in the broader scope of schools.
\end{abstract}

Keywords: metacognition, regulation of cognition, character education, primary education 


\section{Introduction}

As the globalization era grows rapidly, the challenge in the educational world is on the increase. The interconnectedness of the global economy, ecosystem, and political networks requires that students learn to communicate, collaborate, and problem-solve with people worldwide (Saavedra \& Opfer, 2012). Under those circumstances, teachers need to embrace the effective teaching-learning process through their different style in presenting ideas and concepts, develop research, do devotion, and spread knowledge (Gunawan, Mayasari, Muna, \& Masruddin, 2019). Teachers should not only focus on teaching to the test, but teachers should also teach what students need to be successful in life (Anderson, 2016; Beteille and Evans, 2019). Bearing this in mind, teachers are required to have the knowledge of $21^{\text {st }}$-century teaching that teachers are going to be successful in transferring the

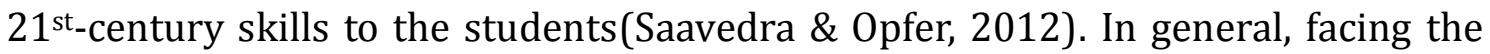
challenges of the $21^{\text {st }}$ century requires a deliberate effort to cultivate in students' personal growth and the ability to fulfill social and community responsibilities as global citizens (Bialik, Michael, Charles, \& Michaela, 2015).

In other words, education needs to guide the students to experience the holistic process of learning. Starting from primary education, it is worth noting that students are excellent learners through a diverse of senses that they must always be mindful of three domains of learning; they are: cognitive, psychomotor, and affective (Wilson, 2019; Masruddin, 2018; Anderson, 2016; Anderson et al, 2001). Another key point, metacognition should also be integrated into the teaching-learning process for it fosters the process of self-reflection and learning how to learn; it serves as the building of those three domains of learning (Bialik et al., 2015). Those domains of learning, psychomotor, affective, and metacognition, should always be taught through the lens of competence. Thus, it can be implied that teachers are responsible for making those four domains of learning balance. The balance of those four domains of learning is the key for the students to be successful at school and society. Research has shown that students' capacities beyond academic learning of knowledge and skills are important predictors of achievement and that it proves useful once in the workspace (Farrington et al., 2012).

At the same time, the progress of technology and the digital era are two sides of the same coin. Masruddin (2018) states that the use of technology as the teaching media may attract the students to be interested in learning. However, the rapid progress of technology is also dealing with how a person make an ethical decision. As an illustration, people who live in the digital age are often exposed to fake news or hoaxes. In this case, some people might verify the news that they have received; meanwhile, some others might be barely able to detect that fake news. Ironically, earlier last year, news about the "Momo Challenge", an alleged challenge on social media encouraging children to harm themselves featuring a scary-looking sculpture, spread on the internet (Valentina, 2019). Furthermore, the learners of the United Kingdom tend to obtain the impacts of the advanced development of 
Elisabeth Avryanne Suminto \& Concilianus Laos Mbato

The Implementation of Metacognition in Teaching Character Education in Primary Education

science and technology that those learners begin to show harmful behavior, anti-social behavior, indiscipline, and underachievement (Arthur, 2005). Gott (2003) also puts in writing, "Over recent years mental health initiatives in schools have proliferated, varying considerably in range and focus."

It is important to realize that a child of the age between 5 and 6 years is most likely trying to act out his or her fantasies and do an imaginative role-play (Malik \& Marwaha, 2019). Besides, a five-year-old child with higher levels of development should imitate more than peers with lower levels of development (Fouts, G. \& Liikanen, 1975). In brief, young children, who go to primary school, are more likely having the tendency of imitating what they observe. As the children are shown good attitudes, they would likely follow it. Unfortunately, as the children are shown bad attitudes, they would also easily imitate it. Thus, significant persons around young children should always be aware of being a good role model for children.

It is through the sense of personal and ethical responsibility that students, the citizens of the future, will be able to make knowledgeable and wise decisions that address the challenges above (Bialik et al., 2015). People may attest that primary education is the foundation of the formation of human personalities, such as teaching how to behave decently in everyday life (Gunawan, 2017). In the first place, it is undeniable that parents play a significant role in shaping the character of the children at home. Furthermore, teachers are also responsible for introducing the values of behavior in society to the children.

Tarakanita Magelang Primary School has been implementing character education in its curriculum. This school has been implementing the curriculum of 2013 from the first grade to the sixth grade. In detail, the government emphasizes the implementation of curriculum 2013 that primary school is required to empower the quality of education on values, attitudes, and character. Curriculum 2013 aims to motivates the students to make use of their knowledge, character, and skill to contribute to the welfare of humanity (Hasan, 2013). On top of that, Tarakanita Magelang Primary School also implements character education through the implementation of Kurikulum Cc5+ Tarakanita (Curriculum of Cc5+ Tarakanita). The character education of Tarakanita strives for shaping the students who spark a sense of compassion, celebration, competence, conviction, creativity, and community (Kongregasi Suster-Suter CB, 2019/ Congregation of Sisters of Charity of Saint Charles Borromeo, 2019).

In general, the research on character education by Indonesian researchers had been emphasized through the lens of a particular school subject; Indonesian researchers focused on metacognitive strategies to help students to excel in academic life (cf. Sungkawati, 2014; Sofyan, 2017). However, none of this research focused on nurturing character education through the lens of metacognition. This study served to fill in the gap and enrich the current research by reporting a mixed-method research on the character education which was taught through the lens of metacognition. This study focused on two research questions as follows: 1. what are the teachers' perceptions on the implementation of metacognition in 
teaching character education?; and 2. to what extent does the implementation of metacognition in character education lead the teachers to school vision?

\section{Metacognition}

Whitebread et al (2009) document a number of studies which indicate the evidence of young children's metacognitive abilities; these studies demonstrate that although young children may not be able to describe the metacognitive process they are exhibiting, it does not mean that these processes are not occurring. Therefore, primary school teachers are required to embed metacognition in their everyday teaching-learning process. According to Flavell (1979), metacognition is dealing with both knowledge and cognition on the phenomena of cognitive, through which there is an accomplishment of the cognitive monitoring process.

Furthermore, metacognition is related to a person's thinking process that he or she is aware of the process of thinking on his or her mind (Anderson, 2001). In the classroom, metacognitive knowledge refers to capability of the children to understand themselves as the learners, to understand how the children learn, and to be aware of the stages and actions that they carry out during the learning process or to reach the learning outcome of a certain subject (Tarrant \& Holt, 2016). Generally speaking, metacognition is the key to be successful in learning as the learners are totally mindful of what and why they are learning.

Furthermore, Brown (1987) as cited in Mbato (2013) proposes that there are two different frameworks of understanding metacognition; they are: knowledge of cognition and regulation of cognition. Knowledge of cognition is dealing with what a person knows about his cognition or cognition in general; it may cover three different kinds of metacognitive awareness. They are: declarative, procedural, and conditional knowledge (Jacobs \& Paris, 1987; Schraw \& Moshman, 1995). Regulation of cognition is dealing with the ways of the learners regulate their learning process; it may include: planning, monitoring, and evaluating processes (Brown, 1987, as cited in Mbato, 2013). In the process of learning character qualities, students' participation is not only related to physical activity, but it is also linked to students' awareness of their knowledge as well as the awareness which should be set to learn and solve the problem and to learn (Murtafiah., Masrura, Si., Indrawati, Arsyad, N., \& Awi, 2018).

In particular, Bromley (2018) proposes that as the planning process happens, the teachers may guide the students to set the goal of their learning and how they are going to tackle the task. In this stage, the teachers may help the students to: (1) make certain that the students perceive the intended goal of learning, (2) recall the existing prior knowledge which is related to the task (3) carefully choose the most suitable strategies, and (4) think about how to manage their effort (Bromley, 2018). Moreover, in the monitoring process, students, as the teachers help them, are required to implement their plan and monitor their progress in learning. They are asked to see whether they are moving onward on the right track towards their learning goals. During this stage, students may make a choice to change their 
The Implementation of Metacognition in Teaching Character Education in Primary Education

strategy on learning if that strategy is working (Cambridge International Education Teaching and Learning Team, 2019).

Also, evaluation process might help the students to see whether the strategy they have implemented have helped them to achieve the learning goal; in order to promote evaluation, teachers need to guide the students to think about how well did they do, what did not go well, and how will the students utilize the new knowledge (Cambridge International Education Teaching and Learning Team, 2019). Furthermore, reflection appears to be a significant part of the plan-monitor-evaluate process that it is not only dealing with the learning process but it is also dealing with students' emotions; students are given the time to reflect on what they love about the learning process and the way they cope up with the emotions (Cambridge International Education Teaching and Learning Team, 2019; Parent 2017).

Teachers need to introduce metacognitive strategies to the students that it may encourage the students to engage in learning character education. Mbato (2013) proposes that a metacognitive approach requires learners to have appropriate strategies at their disposal (p. 13). Studies have proven that the most effective learners may have a large number of strategies which are varied from the simplest to the most complex ones; those strategies are also possibly combined to address the task demands (Reid, Lienemann, Hagaman, 2013).

Another key point, character education is a system that inculcates the values of character to the citizens of the school, which includes the components of knowledge, consciousness, and the act of applying the values of the God Almighty, self-values, fellow, environment, and nationality (Murtafiah. et al., 2018). Another key point, character education is the process when teachers attempt to internalize the character qualities to the students through the teaching-learning process. In Tarakanita education, the character qualities which are learned may include Cc5+ Tarakanita; they are: compassion, celebration, competence, conviction, creativity, and community.

Compassion is one of the character qualities which are taught in Tarakanita Magelang Primary School. Compassion is built by acts of care, solidarity, and sharing by giving (Todarung et al, 2017). Then, the character quality of celebration is built by the dimensions of showing gratitude and having faith (Todarung et al, 2017). While competence is the ability of the students to strive for excellence; excellence and intelligence should always be followed by the skills and character qualities (Todarung et al, 2017). In detail, competence may cover two aspects; they are being independent and owning a scientific attitude (Todarung et al, 2017). Independent study, continuous learning, and making use of one's own experience belong to the criteria of being independent (Todarung et al, 2017). Having a sense of curiosity, being open-minded, being objective, following a set of procedures, and being dynamic belong to the criteria of owning a scientific attitude (Todarung et al, 2017). In addition, the character quality of conviction is built by the dimensions of perseverance and strength (Todarung et al, 2017). Creativity is built by the act of 
being creative and innovative (Todarung et al, 2017). Having a certain sense of imagination, being able to solve the problem, and being able to present the best work are the indicators of the act of being creative (Todarung et al, 2017). While, the character quality of community is built by the dimensions of appreciating oneself, appreciating others, and collaborative work (Todarung et al, 2017).

\section{Method}

This study was a mix-method study. Mixed method designs are procedures for collecting, analyzing, and mixing both quantitative and qualitative data in a single study or a multiphase series of studies (Cresswell, 2012). This study was conducted by using both closed-ended and open-ended questionnaires as well as an in-depth interview as the methods for collecting the data. In general, the writers emphasized the perceptions of the primary school teachers on the implementation of metacognition in character education. All of the data which were collected in this study were presented in the form of a narrative that it may help the people to acquire a better understanding of the results of this study.

This study was limited to the implementation of character education in primary education. The participants of this study were the Primary School teachers of Tarakanita Magelang Primary School. There were twenty one teachers who taught at Tarakanita Magelang Primary School. The age of the participants was varied that they were between twenty three years old up to fifty four years old. Moreover, the range of teaching experiences varied. The teaching experiences were ranging from one year to more than twenty years.

In this study, the writers utilized a closed-ended and open-ended questionnaire. The questionnaires were given to the teachers. The questionnaires were not given to the kids for they were too young; the kids were also protected that they were still under seventeen years old. As the writers had acquired the data from the questionnaire, the writers might start to conduct an in-depth interview with four teachers of Tarakanita Magelang Primary School. The interviewees were chosen based on their responses to the given questionnaire.

In analyzing the quantitative data, the writers made use of the Likert scale to calculate the data. The writers analyzed the quantitative data of the questionnaire by using descriptive statistics. The writers calculated the responses of the participants and calculated the raw data then presented them in bar charts. Moreover, the qualitative data of the open-ended questionnaire and the interview were analyzed in the form of a descriptive narrative. The qualitative responses were coded into the similar themes and then it was presented in a narrative account.

\section{Results}


The Implementation of Metacognition in Teaching Character Education in Primary Education

The writers classified the results from both of the questionnaire and the interview into two different parts; they were: how the teachers perceived the process of implementing metacognition in teaching character education and the extent to which the implementation of metacognition in character education led the teachers to school vision.

\section{Teachers' Perceptions on the Implementation of Metacognition in Teaching Character Education}

In general, the teachers implemented metacognition, especially in nurturing the character qualities of the students. According to the data, most teachers had applied the steps of regulation of cognition; they were: planning, monitoring, and evaluating process (Brown, 1987, as cited in Mbato, 2013). The details of the processes were written below.

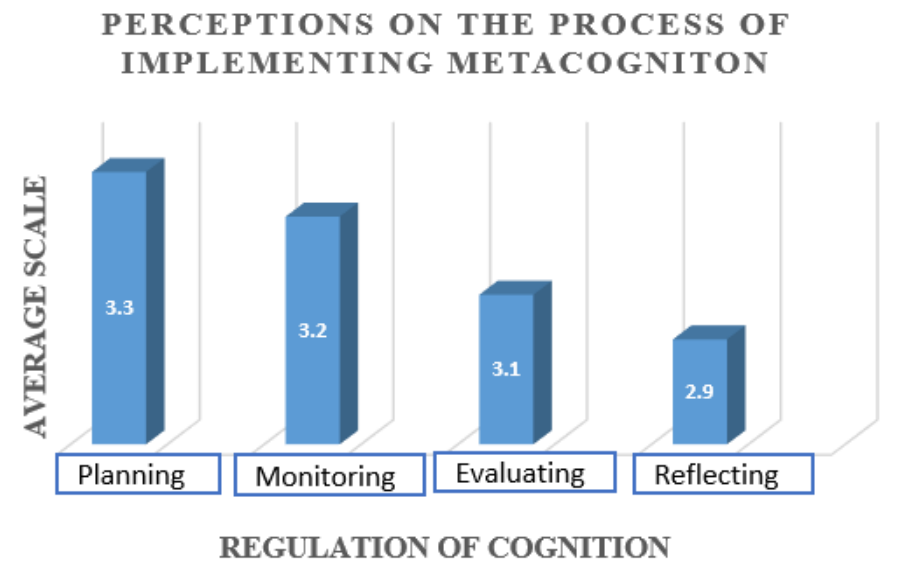

Figure 1. Perceptions on the Process of Implementing Metacognition

\section{Planning}

The data from the closed-ended questionnaire showed that the majority of the participants attested that they planned for their lesson in advance (3.3 of 4.0). In detail, most teachers chose to agree and strongly agree that they were diligent in designing the lesson plan for every meeting. In addition, all of the teachers chose to agree and strongly agree that they tried to relate the existing knowledge with the upcoming materials to learn. As has been noted, the participants showed positive perceptions on planning that they generally made plans before teaching.

Furthermore, in the interview, all of the four teachers confirmed that they always prepared the materials to teach one day before they taught the students. There would not be any successful learning process without any preparation (Cyrillus, interviewee 2). One of the interviewees, Elena, also added that planning might cover setting up the goals of learning.

"After the morning prayer, the students and the teachers always sing the national anthem. After that, I begin the lesson by stating the goals of learning that day. I let the students know what they are going to do and achieve in today's lesson." (Elena, interviewee 1) 
As has been noted, all of the teachers had planned for their teaching-learning process.

Monitoring

Based on the questionnaire statement number three and four, all teachers agreed and strongly agreed that they observed and checked the progress of the study. Furthermore, most of the teachers agreed that they encouraged the students to see the things which were needed to be improved within the teaching-learning process. On the whole, it was worth noting that most of the teachers applied monitoring strategies in their teaching-learning process (3.2 or 4.0).

Based on the interview, one of the interviewees stated that the students were also observed how they behaved, how they talked, and how they treated their friends (Elena, interviewee 1). Moreover, both Errick and Cyrillus added that sometimes the teachers needed to control the students with a loud voice. The students were sometimes needed to be situated in the studying ambiance with a loud voice. Cyrillus stated, "Having a good classroom management may lead us to fifty percent of succeeding in the learning process. In this case, small kids are barely able to be awaited. If we need to deliver our loud voice, we do it."

On the contrary, Louis disagreed with the statement that managing the students in class required a loud voice; Louis believed that it was more about the didactical, methodological, and pedagogical skills of the teachers. At the same time, Louis elaborated that classroom management appeared to be a part of the monitoring stage that allowed the teacher to manage the dynamics of the classroom.

\section{Evaluating}

In particular, based on the questionnaire, the teachers had implemented the evaluation process in their teaching-learning process. It was indicated by 3.1 of 4.0 of the teachers chose to agree that they encouraged the students to think about what things needed to be improved in the learning process. Also, most teachers felt that they did not have practical difficulty in assessing the affective aspect.

In general, based on the interview, all interviewees confirmed that they did the evaluation in every meeting. Two of the interviewees attested that they generally did the evaluation by conducting a question and answer session at the end of the lesson. One interviewee affirmed that he usually asked the students to do a simple exercise to wrap up the lesson. Equally important, the evaluation needed to be in line with the goals at the beginning of the lesson, as Cyrillus added,

"We need to pay attention to our learning goals, which were set at the beginning of the lesson. Thus, we might start, deliver, and finish the lesson accordingly to the goals and the indicators of learning to achieve. As we have told the students our goals of learning at the beginning of the lesson, the evaluation will be dealing with the learning goals. Take for instance, I would like to assess the affective aspect. I focus on the community as the 
character quality. I observe how the students engage themselves during the group discussion by using a checklist."

All things considered, the majority of the teachers evaluated their teaching-learning process. They carried out the evaluation process for the cognitive aspect in various ways. They were: conduction a question and answer at the end of the lesson and asking the students to solve a simple exercise. For the affective aspect, the teacher prepared for the checklist to assess the students.

\section{Reflecting}

Based on the questionnaire, the majority of the teachers invite their students to reflect on their study. It was indicated by 2.9 of 4.0 teachers agreed that they had enough time for doing reflection at the end of the lesson. Departing from these statements, the majority of the teachers agreed that they encouraged the students to reflect on how they felt throughout the lesson.

Based on the interview, all of the four interviewees might invite the students to do the reflection. In detail, two interviewees confirmed that they regularly asked the students about their feelings; the teachers asked whether the students were happy with the lesson or not. Cyrillus confirmed,

"Reflections need to be done at the end of the lesson. We ask the students how they find the lesson. We may also ask about their feelings whether they are happy and whether the lesson they have learned is meaningful for their lives." (Cyrillus, interviewee 2)

Also, the other two interviewees claimed that they did reflections when their students behaved in an undesired way. The teachers usually talked with the students and asked some reflective questions to them.

"As the class is getting noisy, I ask the students to stay silent. I do not need to tell them in a loud voice. I normally guide them to think with the reflective questions; for example: if the class is so noisy, who do you think will be annoyed?" (Louis, interviewee 4)

\section{Teachers' Perceptions on the Effects of Implementing Metacognition in Teaching Character Education}

In this part, the writers elaborated the perceptions of the teachers on the effects of implementing metacognition in teaching character education to the students. In general, the effects of implementing metacognition in teaching character education might be dealing with the character qualities of compassion, celebration, competence, conviction, creativity, and community. 


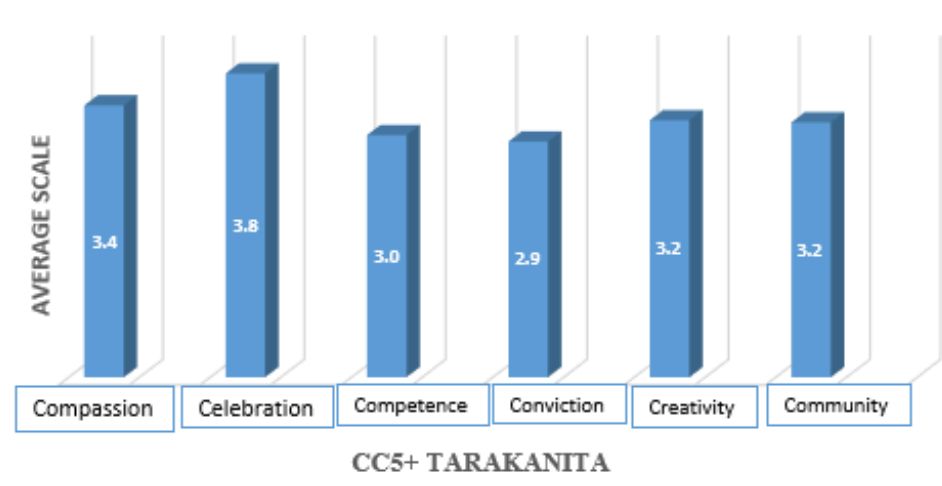

Figure 2. The Effects of Implementing Metacognition

\section{Compassion}

As a matter of fact, the majority of the teachers, which were 3.4 of 4.0 , chose to agree that compassion could be taught to the students by asking them to work together with their friends as well as by inviting them to donate the money for the church. Based on the open-ended questionnaire, as the teachers were asked to choose three character qualities, which were the easiest to teach, twelve teachers stated that compassion was one of the first character quality which could be planted in the students. In particular, compassion was taught through peer-studying and group-working, sharing the lunch meals and the social fund, and telling inspirational stories which were related to everyday life.

Damian, one of the participants, wrote, "The students are asked to work together with the friends sitting beside them. During the process of working together, they learn how to show care for other friends." Based on the interview, two of the interviewees agreed that compassion appeared to be one of the character qualities which could easily be taught to the students.

"Compassion is the value which is reflected throughout the everyday lives of the students. Every Monday, the students are usually asked to collect the money for the social fund." (Louis, interviewee 4)

\section{Celebration}

Figure 2 showed that 3.8 of 4.0 of the participants agreed that the students had developed in the character quality of celebration. The majority of the teachers agreed that the students always began and ended the lesson with prayer; the students also had the bravery to lead the prayer in front of the class.

In the same way, based on the open-ended questionnaire, there were eleven teachers stated that celebration was the second character quality which was taught with few difficulties. In particular, the teachers invited the students to pray in a good gesture as well as encouraged the students to be thankful for simple things. Andrea wrote, "I promote the celebration by motivating the students to be thankful for their friends and their opportunity to go to school. I also encourage them to be 
The Implementation of Metacognition in Teaching Character Education in Primary Education

thankful for every grade they have got during this semester." Also, based on the interview, two of the interviewees affirmed that celebration was one of the most observable values which was reflected on students' everyday life. One interviewee stated,

"The character of celebration is reflected on how the students take care of their own belongings as well as the school facilities. A student who has celebration as part of his or her character quality may not be ignorant of the things that belong to him or her. He or she may have a good sense of belonging to the things he owns." (Cyrillus, Interviewee 2)

\section{Competence}

From the open-ended questionnaire, there were eleven teachers chose competence as the character quality needed to be taught to the students. The teachers might lay emphasis on the teaching-learning process that helped the students to master the subject to learn. Salvius, one of the participants, wrote, "I let the students study the subjects and materials. I do promote a large number of problems for the students to solve."

Furthermore, Figure 2 showed that 3.0 of 4.0 of the participants agreed that the students were capable of doing the task independently. Also, the teachers perceived that the students were brave enough to ask questions in the learning process. Based on the interview, two of the interviewees confirmed that competence appeared to be one of the values which was needed to be nurtured. Errick stated,

"Doing an individual task may help the students to be independent learners. However, there is a problem with the slow-learning students. They seem to do their task on their own but it turns out that the result is not that good. Slow-learning students need intensive guidance in learning." (Errick, Interviewee)

\section{Conviction}

The results of the closed-ended questionnaire showed that 2.9 of 4.0 of the teachers perceived that the students had developed their conviction well. It was indicated by the majority of the teachers who agreed that the students tend to submit the work on time. Also, the majority of the teachers agreed that the students might struggle to finish the task at school.

Based on the open-ended questionnaire, conviction appeared to be the first-three important value to be taught to the students. There were ten teachers chose conviction as a significant value to consider. In general, the teachers focused on motivating the student so that they would not give up as they faced the obstacles. The teachers also supported the students by delivering positive verbal encouragement. Nina, one of the participants, put in writing, "I encourage my students to keep trying even after they have experienced failure. I tell them not to give up and not to lose hope. I always support them to excel beyond their limit." 
Based on the interview, two interviewees affirmed that conviction needed to be taught to the students. Elena stated,

"I always have a jargon for my student. 'I can do it!' Whenever my students complain that the task is too difficult, I always repeat the jargon and the students follow after." (Elena, interviewee 1)

\section{Creativity}

According to Figure 2, 3.2 of 4.0 of the participants agreed that the students were capable of expressing their thoughts; also, the students were able to present the results accordingly to the criteria. In like manner, based on the open-ended questionnaire, the teachers put in writing that creativity was taught by delivering an interesting teaching strategy, letting the students engage in games of problem-solving, and presenting in front of the class. Irene, one of the participants, wrote, "The students are given the task which requires creativity to accomplish it. Take for instance, the students are asked to present in front of the class. The students are also given cases and are asked to find the solutions."

Based on the interview, one interviewee confirmed that creativity was taught by giving the examples first.

"At first, I give chances for the students to create a yel-yel. To begin with, I change the lyric of a children's song. Then, the students were able to create the lyric on their own." (Elena, interviewee 1)

\section{Community}

Based on Figure 1, the majority of the teachers agreed that the students had developed their character quality in terms of community. It was indicated by 3.2 of 4.0 of the teachers chose to agree with the statement that the students were capable of considering others' opinions as well as respect others who were speaking in the classroom.

Based on the open-ended question, the teachers brought a sense of community by asking the students to work in a group. Fabian, one of the participants, wrote, "The students are usually asked to clean the classroom together fifteen minutes before going home. They do learn to work together with other friends. This might cultivate the sense of brotherhood and sisterhood among the students." Moreover, one of the interviewees also attested that community could possibly be built by assigning the students to work together.

"We can assign the students to work together. Make them worked in a group of six. Give them a topic to discuss. Those six persons may have different opinions; some other students might complain as well. Let it be; we create this learning ambiance on purpose. Later on, we may lead them to see that differences will always be there. The thing to consider is that how we cope up with those differences. We might win without beating others. We create the learning ambiance as real as possible." (Cyrillus, interviewee 3)

\section{Discussion}


It was worth noting that the teachers had positive perceptions on the process of implementing metacognition in teaching character education at Tarakanita Primary School. In general, the teachers chose to agree to the most statements of the closed-ended questionnaire. In other words, the teachers had positive perceptions on the four stages of implementing metacognition strategies. As has been noted, based on the theories about regulation of cognition, the process of implementing regulation of cognition was done through the stages of planning, monitoring, evaluating, and reflecting (Brown, 1987, as cited in Mbato, 2013; Cambridge International Education Teaching and Learning Team, 2019; Parent 2017).

In the first place, the teachers had positive perceptions on planning, monitoring, evaluating, and reflecting. Take for instance, the majority of the teachers affirmed that they planned for their lesson in advance (3.3 of 4.0). It was attested that most of all of the teachers implemented planning before teaching. However, each teacher might have different strategies in implementing planning on their teaching. Teachers needed to guide their students to set the goal of learning and how they were going to tackle the task (Bromley, 2018).

Teachers were also expected to monitor their ways of teaching. One of the basic idea of monitoring was dealing with the process of implementing the plans of the teachers as well as monitoring the progress of the teachers had made towards their learning goal (Cambridge International Education Teaching and Learning Team, 2019). As the students were working on their task or studying, the teachers might pay attention to each of them; the teachers might observe the ways of the students working on their task. It was attested by one of the interviewees that the students were observed how they behaved, how they talked, and how they treated their friends (Elena, interviewee 1).

Another key point, evaluation played a significant role in teaching character education. Evaluation process was helpful for the students as they would be capable to see whether they had applied appropriate strategy to achieve their goal (Cambridge International Education Teaching and Learning Team, 2019). The teachers had positive perceptions on evaluation that it indicated by 3.1 of 4.0 of the teachers who agreed that they encouraged the students to think about what things needed to be improved in the learning process.

Besides, reflection was essential as it enable the students to understand their own emotions; students needed to reflect on what they love about the learning process and how they cope up with the emotions (Cambridge International Education Teaching and Learning Team, 2019; Parent 2017). Teachers were aware of the importance of wrapping up the lesson through interview. It was proven by one of the interviewees, Cyrillus, who confirmed that teachers needed to ask about the students feeling. It was shown that teachers embedded reflection in their teaching-learning process.

In terms of the character qualities, the teachers attested that all of the values were developed to different extents. The teachers strived to nurture the 
values of compassion, celebration, competence, conviction, and creativity (Todarung et al, 2017). Based on the closed-ended questionnaire, it was proven that the teachers had successfully nurturing the values of compassion, celebration, competence, conviction, and creativity.

It was attested by the majority of the teachers, which was indicated by 3.2 or 4.0, agreed that the creativity of the students were developed as they were capable of expressing their thoughts. The value of community also developed; it was indicated by the majority of the teachers, which was 3.2 of 4.0 , agreed that the students were capable of considering others' opinions as well as respect others who were speaking in the classroom. Creativity was actually dealing with the ability to have a certain sense of imagination, solve the problems, and present the works; meanwhile, community was dealing with the ways of the students to appreciate themselves and others (Todarung et al, 2017).

Although it was attested that all of the six $C$ values were well-developed, there were four values which were categorized as the most well-developed ones; they were: compassion, celebration, competence, and conviction. Compassion was one of the most well-implemented values in students' lives. It was proven by the open-ended questionnaire indicating twelve teachers who chose compassion. In fact, compassion had a broad scope of subject without making one seem more important than the other. Helping other friends, sharing the knowledge as well as sharing the social fund were some of the subjects of compassion.

Celebration was proven to be one of the well-implemented character qualities. It was attested by one of the teachers who wrote that she promoted the value of celebration through motivating the students to be thankful for their friends and their chances to go to school. The teachers had develop students' competence as well. It was affirmed by Salvius, one of the participants who wrote that he let the students to solve the problems based on the subject to learn. In this case, teachers might introduce the learning culture of being an independent learner as well as owning a scientific attitude to the students (Todarung et al, 2017). Besides, conviction stood as one of the goals in Tarakanita Primary School. It was indicated to be one of the most achievable goals; there were ten teachers who chose it. Conviction should be introduced to the students as it will enable the students to keep on trying right after they experienced failure (Nina, participant).

In conclusion, the teachers of Tarakanita Magelang Primary School had successfully implemented the regulation of cognition in their teaching-learning process to nurture the character education. Besides, the teachers facilitated the students to develop in compassion, celebration, competence, conviction, creativity, and community. However, based on the interview, it was shown that different teachers might able to implement planning, monitoring, evaluating, and reflection to a different degree. In particular, most of the teachers had positive perceptions that they had helped the students to develop their compassion, celebration, competence, and conviction. 
Elisabeth Avryanne Suminto \& Concilianus Laos Mbato

The Implementation of Metacognition in Teaching Character Education in Primary Education

\section{Conclusion}

Based on the finding and the discussion, it was worth noting that the teachers of Tarakanita Magelang Primary School had positive perceptions on the implementation of metacognition in teaching character education. The results of the closed-ended questionnaire revealed that the values of compassion, celebration, competence, and conviction were well-implemented. Despite this positive results, this research had a limitation in that it was conducted in one of Tarakanita schools only. Future researchers may need to conduct a research in a broader scope of school under the foundation of Tarakanita.

\section{References}

Anderson, et al. (2001). A taxonomy for learning, teaching, and assessing. New York, United States: Addison Wesley Longman.

Anderson, J. (2016). Schools are finally teaching what kids need to be successful in life. Retrieved on October $4^{\text {th }}, 2019$, from

https://qz.com/656900/schools-are-finally-teaching-what-kids-need-to-be-su ccessful-in-life/

Arthur, J. (2005). The re-emergence of character education in British education policy. British Journal of Educational Studies, 53(3), 239-254.

Beteille, T. \& Evans, D. (2019). Successful teachers, successful students: recruiting and supporting society's most crucial profession.

Retrieved from http://www.worldbank.org./en/topic/teachers

Bialik, M., Michael, B., Charles, F., \& Michaela, H. (2015). Character education for the 21st century. In Center for Curriculum Redesign. Retrieved from http://curriculumredesign.org/wp-content/uploads/CCR-CharacterEducation _FINAL_27Feb2015.pdf

Bromley, M. (2018, November 21st). In the classroom: metacognition explained. Retrieved from:

http://www.sec-ed.co.uk/best-practice/in-the-classroom-metacognition-expl ained

Cambridge International Education Teaching and Learning Team. (2019, November $11^{\text {th }) . ~ G e t t i n g ~ s t a r t e d ~ w i t h ~ m e t a c o g n i t i o n . ~ R e t r i e v e d ~ f r o m ~}$

https://cambridge-community.org.uk/professional-development/gswmeta/in dex.html

Cresswell, J. (2012). Educational research: planning, conducting and evaluating quantitative and qualitative research. Lincoln: Pearson.

Farrington, C. A., Roderick, M., Allensworth, E. M., Nagaoka, J., Keyes, T. S., Johnson, D. W., \& Beechum, N. O. (2012). Teaching adolescents to become learners. In The Role Of Noncognitive Factors in Shaping School Performance: A Critical Literature Review. Retrieved from papers3://publication/uuid/EDEBF1C9-0E1E-4E6A-BADC-6621FA39A342

Flavell, J. H. (1979). Metacognition and cognitive monitoring: A new area of 
cognitive-developmental inquiry. American Psychologist, 34(10), 906-911. https://doi.org/10.1037/0003-066X.34.10.906

Fouts, G. \& Liikanen, P. (1975). The effects of age and developmental level on imitation in children. Child Development, 46(2), 555-558.

Gott, John. (2003) The School: The Front Line of Mental Health Development? Pastoral Care in Education, 21:4, 5-13,

DOI: $10.1111 / \mathrm{j} .0264-3944.2003 .00272 . x$

Gunawan, R. (2017). The role of character education for early children in early childhood education programs in Happy Kids Bogor Indonesia. 66, 23-26. https://doi.org/10.2991/yicemap-17.2017.5

Gunawan, F., Mayasari, R., Muna , W., \& Masruddin, M.(2019). Lecturer's Language Style and Students' Academic Self Efficacy in Higher Education of Indonesia. Arab World English Journal, 10(2)77-87, DOI: https://dx.doi.org/10.24093/awej/vol10no2.7

Hasan, S. H. (2013). History education in curriculum 2013: a new approach to teaching history. Historia: International Journal of History Education, 14(2), 163. https://doi.org/10.17509/historia.v14i1.2023

Jacobs, J \& Paris, S. (1987). Children's Metacognition About Reading: issues in Definition, Measurement, and Instruction. Educational Psychologist, 22:3-4, 255-278, DOI: 10.1080/00461520.1987.9653052

Kongregasi Suster-Suter CB (Congregation of Sisters of Charity of Saint Charles Borromeo). (2019, October $1^{\text {st }}$ ). Karya pelayanan pendidikan formal kongregasi Carolus Borromeus. Retrieved from http://www.sustercb.com/karya-kerasulan/pendidikan/

Malik, F. \& Marwaha, R. (2016). Developmental stages of social emotional development in children. Retrieved on October $3^{\text {rd }}, 2019$, from https://www.ncbi.nlm.nih.gov/books/NBK534819/

Masruddin, M. (2018). The Efficacy of Using Short Video through Group Work in Teaching Speaking to Indonesian English as Foreign Language (EFL) Students. Arab World English Journal, 9 (3), 282-293.

DOI: https://dx.doi.org/10.24093/awej/vol9no3.19

Masruddin. (2018). Learning style in language learning classroom. Journal of Language Teaching and Learning, Linguistics and Literature, 6 (2), pp. 115-125.

Mbato, C. L. (2013). Facilitating EFL learners' self-regulation in reading: implementing a metacognitive approach in an Indonesian higher education context. EdD Theses, Southern Cross University. Lismore: Southern Cross University. Retrieved on October $7^{\text {th }}, 2019$ from

https://epubs.scu.edu.au/theses/353/

Murtafiah., Masrura, Si., Indrawati, N., Arsyad, N., \&, \& Awi. (2018). The development of learning package based on metacognitive strategies to build the students character. Journal of Physics: Conference Series, 128, 1-6. https://doi.org/10.1088/1742-6596/1028/1/012127

Parent, L. (2017, February 23rd). Building content \& character with metacognition. 
Elisabeth Avryanne Suminto \& Concilianus Laos Mbato

The Implementation of Metacognition in Teaching Character Education in Primary Education

Retrieved from

https://medium.com/open-edtech/building-content-character-with-metacog nition-3e80b2f580ab

Reid, R., Lienemann, T., Hagaman, J. (2013). Strategy instruction for students with learning disabilities. New York, United States of America: The Guilford Press.

Saavedra, A. R., \& Opfer, D. (2012). Learning 21st-century skills requires 21st-century teaching. Phi Delta Kappan, 94(2), 8-13. https://doi.org/10.1177/003172171209400203

Schraw, G., \& Moshman, D. (1995). Metacognitive Theories. Educational Psychology Review, 7(4), 351-371.

Sofyan, M. (2017). EFL learners self-regulated learning strategies in achieving an excellent academic performance. Journal on English Language teching \& Learning Linguistics and Literature, 5 (2), 109-123. DOI: https://doi.org/10.24256/ideas.v5i2.11

Sungkawati, W. (2014). Analisis pendidikan karakter dalam lagu dolanan anak. Journal on English Language Teaching \& Learning Linguistics and Literature, 2 (2), 1-17. DOI: https://doi.org/10.24256/ideas.v2i2.34

Tarrant, P. \& Holt, D. (2016). Metacognition in the primary classroom. New York, United States: Routledge.

Todarung, Y., et al. (2017). Kurikulum Cc5+ Tarakanita. Jakarta: Divisi Pendidikan Yayasan Tarakanita.

Valentina, J. (2019, October 7th). The future of combating hoaxes lies in the hands of gen z. The Jakarta Post, Science \& Tech.

Retrieved from

https://www.thejakartapost.com/life/2019/10/06/the-future-of-combatinghoaxes-lies-in-the-hands-of-gen-z.html

Whitebread, D. et al. (2009). The development of two observational tools for assessing metacognition and self-regulated learning in young children. Metacognition and Learning, 4(1), 63-85.

DOI: https://doi.org/10.1007/s11409-008-9033-1

Wilson, L. (2019). Three domains of learning - Cognitive, affective, psychomotor. Retrieved on October 1st, 2019, from http://thesecondprinciple.com/instructional-design/threedomainsoflearning / 